\title{
Implementing IAS-IFRS in the Moroccan Context: An Explanatory Model
}

\author{
Khalifa Ahsina \\ Dept. of Management, Ibn Tofail University \\ PO Box 2010, Kenitra, Maroc \\ Tel: 212-6-75789297_E-mail: k_ahsina@yahoo.fr
}

Received: July 10, 2012 Accepted: October 03, 2012 DOI: 10.5296/ijafr.v2i2.2524

\begin{abstract}
The International Financial Reporting Standards (IFRS) have been the subject of several research papers, however, this type of work is still absent in Morocco, hence the importance of this research.

This article aims to propose an explanatory model of variables influencing the implementation of IAS- IFRS in the Moroccan context. Based on the contingency theory, we tested the relationship between the adoption of these standards and contingency factors. The analysis of empirical data allows us to observe the influence of these variables on the adoption of international accounting standards.
\end{abstract}

Keywords: IAS/IFRS, Casablanca stock exchange, model logit 


\section{Mll Macrothink}

International Journal of Accounting and Financial Reporting

ISSN 2162-3082

2012, Vol. 2, No. 2

\section{Introduction}

Repeated financial scandals of recent years have rightly pointed out obvious shortcomings of financial reporting system. Clearly, restoring confidence in the market and the reliability of the accounts, reassure shareholders and the public are two priorities today.

In this sense, the European Parliament adopted in July 2002, the rules requiring, beginning in 2005, the application of international standards for consolidated accounts of listed companies, including banks and insurance companies.

In addition, at October 13, 2005, the Securities Ethics Board issued Circular 06/05 on the publication and dissemination of financial information by corporations using savings. The circular stipulates in Article 6 states that synthetic statements should be prepared according to current legislation or according to international accounting standards (IAS / IFRS).

This work focuses, therefore, the choice of the passage made by companies listed on the Casablanca Stock Exchange. The research is based on the observation of the choices made by these companies. In other words, it is based on preferences expressed by them that we implement reflection.

Given the interest of research, we focus our discussion on the choice of transition to IAS / IFRS conducted by the Moroccan companies making public offerings. To organize the study of this phenomenon, we declined our problem into a major research question:

"What are the factors that explain the choice of the transition to IAS / IFRS made by companies listed on the Casablanca stock exchange?"

\section{Theoretical Frameworks:}

The International Financial Reporting Standards (IFRS) have been the subject of several research papers, however, this type of work is still absent in Morocco, hence the importance of this research, because draw up an inventory of research in accounting, management control and audit in Morocco is not easy (Ahsina K 2008).

The positive accounting theory was initiated in the late 1970s by researchers Ross Watts and Jerold Zimmerman. Referring to their university, we talk about school ROCHESTER. The positive theory refers to empirical research in financial accounting and goes against current normative theory (Cormier, 2007).

In this work, our objective by mobilizing the positive theory of accounting is to account for factors associated with choice of transition to IAS / IFRS. Similar to the findings of Holthausen (1990), we place the research in view of the efficiency of contract and, to a lesser extent, we will consider opportunism of managers.

Finally, studies of accounting choices can be devoted either to the study of a particular method (method of inventory valuation, accounting the concentration of the adoption of an accounting. In the context of this research, we are in the context of the study of choice and not the adoption of a repository.

\section{Model hypothesis.}

A modeling to explain the accounting choices of transition, we used an econometric model to 
identify characteristics of positive accounting theory influence the accounting policy of Moroccan companies listed on the Casablanca stock exchange. This model builds on previous research on accounting choices.

We proposed our own explanatory model of transition to IFRS by considering contingency variables such as size of the company, the debt ratio, the distribution of stock option, the presence of controlling shareholders or institutional and international listing.

To WATTS and ZIMMERMAN (1990), "it is clear that there is a relationship between accounting choice and other variables of the firm, as the debt level and size." We retain the traditional variables of positive accounting theory, namely size, leverage and methods of executive compensation. With these fundamentals, we add the shareholding structure, and listing in foreign stock markets. The expected correlation between accounting choice and the transition independent variables are inferred from the literature review. The model aims to bring out the determinants of choice from the estimated explanatory factors. We hypothesize about the meaning of the relationship between potential explanatory factors and the choice of transition to IFRS.

Firm size influences the choice of IFRS accounting: Results confirm the influence of firm size on the choice of accounting policies were highlighted by numerous studies (Watts and Zimmerman, 1990; Raffournier, 1995; HAND and SKANTZ, 1998, Ahsina k 2012). Large companies are more sensitive to pressure from political power than smaller firms.

Hypothesis 1: The largest listed companies tend to opt for the choice of accounting standards internationally recognized.

Loan contracts influence accounting choices: Previous research devoted to Anglo-Saxon countries (DEANGELO et al., 1994; DEFOND and JIAMBALVO, 1994; BALL et al., 2008) demonstrated the influence of contractual clauses related to the rate debt on the choice of accounting practices. However, as emphasized CORMIER et al. (2004), debt contracts rarely include French formal contractual commitments. However, the application of IAS / IFRS has an impact on leverage. Moreover, Marchal et al. (2007) show the growth of debt during the first application of international accounting standards. The authors emphasize that the change in debt was above $10 \%$ in absolute value for $45 \%$ of the groups.

Hypothesis 2: Companies listed on the most leveraged will tend to adopt IFRS in order to improve the debt ratio.

The executive compensation contracts affect accounting choices: The positive theory assumes that managers maximize their utility. Therefore, if they have stock-based compensation, they will tend to manage accounting numbers to maximize the value of their stock options. Williams and Rao (2006) show that managers, part of whose remuneration consists of stock options, have more risky behavior in the management of equity. Accounting choices are assumed to be affected by the opportunism of executives with stock options.

Hypothesis 3: The group plans to distribute stock options to their executives will tend to opt for the international reference IFRS, having a positive impact on equity.

Singhvi and Desai (1971) argue that ownership structure has a significant influence on the 


\section{Al Macrothink}

International Journal of Accounting and Financial Reporting

ISSN 2162-3082

2012, Vol. 2, No. 2

quality of annual reports. It therefore seems necessary to measure the influence of ownership structure on accounting choices during the transition to IAS / IFRS. There are generally two types of shareholders, the majority shareholder in one hand and the institutional shareholder other.

The ownership concentration influences the accounting choices:. The choice of managers depend on the presence of one or more major shareholders. Under these conditions, the pressure on managers is more important and reduces the flexibility in the management of accounting data. A majority shareholder can more effectively control accounting decisions that minority shareholders, because it has sufficient voting power to influence officers or possibly convince other shareholders to support it in case of opposition to the direction of the company (Mtanios and Paquerot, 1999).

Hypothesis 4: the presence of a majority shareholder influences the choice of transition to IFRS.

The influence of institutional shareholders accounting choices: HEALY et al. (1999) show that institutional investors are the agents most demanding in terms of regular financial information and published in due course. Moreover, El-Gazzar (1998) argues that institutional shareholders can influence the choice of groups demanding a new layer of information. Institutional shareholders are active partners in the company, they can choose to influence leaders to force them to increase the performance of the firm (and Mtanios Paquerot, 1999).

Hypothesis 5: the presence of institutional shareholders affects the choice of transition to IFRS.

Thus, as the case, these shareholders may favor standards which result in an increase in equity to reflect the economic value, then, on the contrary, for the sake of transparency of accounts, they can support options having a negative impact on equity.

Listing on a foreign financial influence accounting choices: DUMONTIER and Raffournier (1998), El-Gazzar et al. (1999), ASHBAUGHT (2001) and Cuijpers and BUIJINIK (2005) showed that a listing on a U.S. market encouraged the groups to voluntarily adopt an internationally recognized accounting standards (U.S. GAAP or IAS / IFRS). In these circumstances, we can assume that the firms listed outside of the Moroccan market would tend to choose the nearest repository of European listed companies.

Hypothesis 6: Given these interpretations, companies listed on several stock markets tend to adopt international accounting standards IFRS.

Finally, we introduce variable as the impact of the implementation of IAS / IFRS on the relevance of financial statements. Like Cazavan-Jeny and Jeanjean (2007) as well as BOUKARI and RICHARD (2007), we assume that companies establishing a positive impact will be helped to choose the materials having a negative effect on equity in the objective of minimizing the consequences of the transition.

Hypothesis 7: Firms that have adopted the IFRS are more relevant and reliable financial reporting compared to those who have kept Moroccan accounting.

To explain the accounting choices of transition, we used an econometric model to identify 
characteristics that influence the accounting policy of the companies listed on the Casablanca stock exchange. This model builds on previous research on accounting choices.

The dependent variable model is the choice of transition to IFRS. Each choice is a dichotomous variable. The choice of transition to IFRS is coded " 1 ", while the choice there is no coded " 0 ".

So that the model results are more interpretable, it is necessary that the values of the dependent variable are comparable.

The following explanatory variables were used: firm size, leverage, executive compensation in stock options, shareholder structure and listing on an international financial market. We add as a control variable impact of IAS / IFRS on the reliability and relevance of financial statements.

\section{Research methodology.}

To set the parent population and the sample target of an investigation, there are many highly specialized sampling techniques. We decided not to use given our subject that inherently determines the population under investigation. This work is devoted to the accounting choice of transition to IAS / IFRS conducted by listed companies, except banks, it circumscribes, already, the reference population to listed companies or not applying IAS / IFRS. For each listed company, we collected from the site www.casablanca-bourse.com, the information needed to send the survey: the coordinates of the headquarters, the names of key executives, electronic and telephone contact details of CFOs and / or members of financial communication service. The directory was produced in an EXCEL table, which allowed us to easily export the entire contact list in the mailer.

The first lesson is investigated in the study of response rate, which compares the number of responses to the number of shipments.

Of a total of 69 questionnaires sent, 43 were filled, a response rate of $62.32 \%$ (43/69).

The response rate is very favorable. Recalcitrant companies have been systematically re-launched, often several times and with different interlocutors.

The choice of this statistical model has emerged for two reasons. First, the dependent variable is qualitative, the act of choosing or not the move to IFRS -, thus preventing the use of ordinary multiple regression. And several explanatory variables are qualitative - the existence of a stock option plan, the existence of controlling shareholders and / or institutional or even the impact or not on the relevance of financial statements, which prohibits the use discriminant analysis.

Moreover, the use of logistic regression is common in positive theory of accounting. Thus, in a review of the literature devoted to publications on accounting choices during the 90s, Fields et al. (2001) identify the regression method (including logistics) as a solution to the problem of analysis of accounting choices.

To study a dichotomous dependent variable (in our case "adoption of IAS / IFRS 1" or "non-adoption of IAS / IFRS: 0"), several statistical methods are possible. In this study, we chose logistic regression. 


\section{Macrothink \\ International Journal of Accounting and Financial Reporting \\ ISSN 2162-3082 2012, Vol. 2, No. 2}

Under this method, the model is written as:

$\operatorname{Logit}(\mathbf{P})=\log (\mathbf{P} / 1-\mathrm{P})=\alpha+\beta 1 *$ Size $+\beta 2 *$ Debt ratio $+\quad \beta 3 *$ Stock option $+\beta 4 *$ Presence of controlling shareholders $+\beta 5 *$ Presence of institutional shareholders $+\beta 6$ * Level of reliability and relevance $+\beta 7 *$ industry.

\section{Research Results}

\subsection{Main results of the logistic regression analysis}

The results of binary logistic regressions are presented in the tables below. First we specify the quality of representation of the model and we interpret the results of logistic regressions Explanatory choice of passage, finally, we remember the limitations of logistic regression modeling.

Table 1: League table

\begin{tabular}{|c|c|c|c|c|}
\hline & \multirow[t]{3}{*}{ Observations } & \multicolumn{3}{|c|}{ Forecast } \\
\hline & & \multicolumn{2}{|c|}{ PASS } & \multirow{2}{*}{$\begin{array}{l}\text { percent } \\
\text { correct }\end{array}$} \\
\hline & & 0 & 1 & \\
\hline \multirow[t]{3}{*}{ Step 1} & PASS 0 & 10 & 4 & 71,4 \\
\hline & 1 & 4 & 25 & 86,2 \\
\hline & overall percentage & & & 81,4 \\
\hline
\end{tabular}

The elements necessary for our analysis are summarized in the following table: 


\section{1l Macrothink}

Table 2: Model's variables

\begin{tabular}{|l|l|l|}
\hline \multirow{2}{*}{} & \multicolumn{2}{|c|}{ Choice of transition } \\
\cline { 2 - 3 } & Coefficient & significance \\
\hline Logarithm of sales & 0,694 & 0,003 \\
Distribution of stock options & 0,368 & 0,591 \\
Existence of shareholder & 0,090 & 0,913 \\
Existence of institutional shareholders & 2,036 & 0,087 \\
Debt ratio & $-0,003$ & 0,817 \\
Financial activity & 2,174 & 0,073 \\
Industrial activity & $-0,046$ & 0,962 \\
Industry Goods and Services & $-0,983$ & 0,330 \\
Technology business & 0,147 & 0,917 \\
Constant & $-16,034$ & 0,002 \\
& & \\
& & \\
\hline Total observation & & \\
\hline Chi-square & & \\
Overall percentage & & \\
\hline
\end{tabular}

\subsection{Representativeness of the model}

Overall, the model sheds light on the determinants of the choice of the transition to international accounting standards IFRS. It displays a NAGELKERQUE $\mathrm{R}^{2}$ of $43.6 \%$. This result is correct, which gives the model explanatory power. Work on accounting choices (using logistic regression) are generally nicknames $\mathrm{R}^{2}$ in this standard.

Include model-Missonier PIERA (2004) applied to a sample of 106 Swiss firms with $\mathrm{R}^{2}$ of between $24 \%$ and $29 \%$, as well as the study on the anticipation of IAS / IFRS and Gaeremyn Renders (2007) that displays an $\mathrm{R}^{2}$ of $32 \%$.

However, the pseudo R2 is not sufficient to prove the existence of the relationship between the dependent variable and the explanatory variables. That is why we also analyzed the level of specification of the model through the $\mathrm{Chi}^{2}$ test. For this regression, this test is significant at $1 \%$. The model can be considered explanatory.

The quality of an econometric model focuses on logistic regression can also be approximated by the percentage of correct classification. According SAADA (1995), it is generally considered a dichotomous model is robust when used to classify correctly at least half of the firms in the sample. In this case, the figure is over $81 \%$, which is satisfactory. 


\section{Mll Macrothink}

International Journal of Accounting and Financial Reporting

ISSN 2162-3082

2012, Vol. 2, No. 2

\subsection{Discussion:}

The econometric model allows us to highlight the factors influencing the choice whether to adopt international accounting standards

Now, we will detail the results of the logistic regression:

Choice of passage and size of the company:

The model highlights a positive relationship between the decision to adopt IFRS and company size $(0.694$; sig. <0.003). This result is explained by the ability of large companies to reduce the amount of the net position considering that the adoption of IFRS will have a positive impact on equity. Thus, companies found a positive impact after restatements have opted for mandatory IFRS in order to reduce the effects of the transition to international accounting standards. In addition, the expected losses in equity, may cause an increase in debt which, in itself, is not desirable for groups already heavily indebted.

\section{Existence of institutional shareholders and choice of adopting IFRS:}

The model highlights the positive relationship between the presence of an institutional shareholder and the choice of transition to IFRS (2.036, sig. <0.09). Companies in which institutional shareholders hold a share of the voting rights have tended to adopt international accounting standards. This choice can meet a desire for transparency of institutional investors preferring to reset the translation differences at the transition rather than maintaining differences not comply with IAS / IFRS, or recalculate data retrospectively in accordance with IAS 21. In addition, some companies, anticipating a future sale, will choose the way to increase the profit of the sale.

The choice of adopting IFRS formulated by institutional shareholders reflects the desire to make the financial statements more transparent and lead to a more accurate view of the net worth of companies listed on the Moroccan.

\section{Choice of adopting IFRS and influence of the financial sector:}

The inclusion of sectors in the explanatory model of choosing adoption brings some new elements for understanding the choices. Thus, the model highlights a positive and significant relationship between the choice of passage and belonging to the financial sector (2.174, sig. $<0.073$ ). This finding means that financial firms have tended to adopt standards that give more importance to the financial aspect of the financial statements. Latter also believe that this choice will not impact on the amount of equity, but affect their structure, and will also have an effect on the outcome of future sales.

The results presented are particularly interesting because they analyze the accounting choices of a panel of companies listed on the Casablanca Stock Exchange and reflect the choices made by the companies most affected by IFRS.

In conclusion of the logistic regression analysis, we can draw a table that summarizes the results of hypothesis testing. 


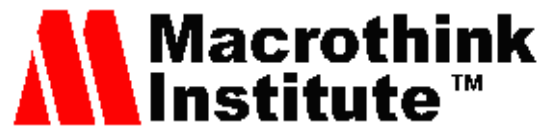

International Journal of Accounting and Financial Reporting

Table 3: Test Results of hypothesis according to logistic regression analysis

\begin{tabular}{|c|c|c|c|}
\hline $\mathrm{N}^{\circ}$ & Title of Hypothesis & variables tested & Results \\
\hline 1 & $\begin{array}{l}\text { "The largest companies tend to opt for the choice of } \\
\text { an internationally recognized accounting standards" }\end{array}$ & Size of the firm & validated \\
\hline 2 & $\begin{array}{l}\text { "The higher the ratio of debt to equity is high, more } \\
\text { listed companies tend to adopt IFRS" }\end{array}$ & Ration of debt & rejected \\
\hline 3 & $\begin{array}{l}\text { "The group plans to distribute stock options to their } \\
\text { executives will tend to opt for the international } \\
\text { reference IFRS" }\end{array}$ & $\begin{array}{l}\text { Existence of stock option } \\
\text { plans }\end{array}$ & rejected \\
\hline 4 & $\begin{array}{l}\text { "The presence of a majority shareholder influences the } \\
\text { choice of transition to IFRS" }\end{array}$ & $\begin{array}{l}\text { Presence of majority } \\
\text { shareholders }\end{array}$ & rejected \\
\hline 5 & $\begin{array}{l}\text { "The presence of institutional shareholders influence } \\
\text { the choice of the transition to IFRS" }\end{array}$ & $\begin{array}{l}\text { Presence of institutional } \\
\text { shareholders }\end{array}$ & validated \\
\hline 6 & $\begin{array}{l}\text { "Companies in certain industries tend to adopt } \\
\text { international accounting standards IFRS" }\end{array}$ & Industry & validated \\
\hline 7 & $\begin{array}{l}\text { "Companies that have adopted the IFRS are more } \\
\text { relevant and reliable financial reporting compared to } \\
\text { those who have kept the General Accounting } \\
\text { Standards Code" }\end{array}$ & $\begin{array}{l}\text { Relevance of IFRS } \\
\text { statements }\end{array}$ & rejected \\
\hline
\end{tabular}

\section{Conclusion.}

The main question of this study was formulated as follows: what are the factors that explain the choice of the transition to IAS / IFRS made by companies listed on the Casablanca stock exchange?

We responded by highlighting the influences on firms during the selection process of passage. Decisions depend on the size, the composition of the shareholders and the industry. Similarly, financial and human resources allocated to projects IFRS are crucial in the process of choice.

The transition to IAS / IFRS has been a rich period for the accounting practice since the transformations it has induced in the financial statements but also in the same business organization. This change has introduced a radical uncertainty at the heart of accounting Moroccan design changes and accounting practice. In an uncertain environment, the firm seeks recognition of the socio-economic environment by adopting a repository recognized by the community. Moreover, it is under pressure exerted by formal and informal institutions accountable. Projects of international standard-setter, the IFRIC interpretations, and recommendations of the Ethical council of securities or positions of the National Council of 
accounting are all components of the decision process, not to mention the weight of the accounting profession.

Finally, the choice of the transition is largely subject to the behavior of preparers. Thus, the normative and technical complexity of IAS / IFRS has highlighted the limited cognitive capacities of practitioners who are not able to capture the entire body optimally, much less to anticipate the effects of the passage of the financial statements.

\section{References}

1. Ahsina K. 2012. Ten years of research in Accounting, Controlling and Audit in Morocco: a bibliographical approach. SS International journal of Business and Management Research Vol.2, Issue 4, July.

2. Ahsina, K; (2012) .Management control systems and performance: essay of modeling. Kuwait Chapter of Arabian Journal of Business and Management Review Vol. 1, No.9; May.

3. Deangelo, H., Deangelo, L., Skinner, D., (1994), "Accounting choice in troubled companies",Journal of accounting and economics Vol.17, n¹-2, pp.113-143.

4. Ball, R., Bushman, R., Vassari, F., (2008), "The debt-contracting value of accounting information and loan syndicate structure", Journal of accounting research, Vol.46, n ${ }^{\circ}$, pp.247-288.

5. Cormier, D., Andre, P., Charles-Cargnello, E., (2004), "Incentives for consolidation of finance subsidiaries: evidence from France", International Journal of Accounting, Auditing and Performance Evaluation Vol.1, n², pp.164-182.

6. Cormier, D., Demaria, S., Teller, R., (2007) "First time adoption of IFRS, management incentives and stock market assessment: some french evidence", Cahier de recherché 2007-05, ESG-UQUAM.

7. Holthausen, R., (1990), "Accounting method choice", Journal of Accounting and Economics, Vol.12,n 1-3, pp.207-218.WATTS and ZIMMERMAN (1990, p.132

8. Defond, M., Jiambalvo, J., (1994), "Debt covenant violation and manipulation of accruals", Journal of accounting and economics, Vol.17, n¹-2, pp.145-176.

9. Marchal, S., Boukari , M., Cayssial, J. L., (2007), "L'impact des normes IFRS sur les données comptables des groupes français cotés ", Bulletin de la banque de France, Vol.163, 27-43.

10. WILLIAMS, M., RAO, R., (2006), "CEO stock options and equity risk incentives", Journal of Business Finance \& Accounting, Vol.33, n 1, pp.26-44.

11. Singhvi I, S., Desai, H., (1971), "An empirical analysis of corporate financial disclosure", Accounting review, Vol.46, n¹, pp.129-138.

12. Mtanios, R., Paquerot, M., (1999), "Structure de propriété et sous performance des firmes : une étude empirique sur le marché au comptant, le règlement mensuel et le 
second marché", Finance contrôle stratégie, Vol.2, n4, pp.157-179.

13. Healy, P., Hutton, A., Papelu, K., (1999), "Stock performance and intermediation changes surrounding sustained increases in disclosure", Contemporary accounting research, Vol.16, n³, pp.485-520.

14. El-Gazzar, S., (1998), "Predisclosure Information and Institutional Ownership : A Cross-Sectional Examination of Market Revaluations During Earnings Announcement Periods", The accounting review, Vol.73, n¹, pp.119-129.

15. Dumontier, P., Raffournier, B., (1998), "Why firms comply voluntarily with IAS: an empirical analysis with Swiss data", Journal of international financial management and accounting, Vol.9, n³,pp.216-245.

16. El-Gazzar, S., Finn, P., Jacob, R., (1999), "An empirical investigation of multinational firms' compliance with international accounting standards", The International Journal of Accounting, Vol.34, n², pp.239-248.

17. Ashbaught, H., (2001), "Non-US firm accounting standard choices", Journal of accounting and public policy, Vol.20, $\mathrm{n}^{\circ} 2, \mathrm{pp} .129-153$.

18. Cuijpers, R., Buijinik, W., (2005), "Voluntary adoption of non local GAAP in the European Union: a study of determinants and consequences", European accounting review, Vol.14, n³, pp.487-524.

19. Cazavan-Jeny, A., Jeanjean, T., (2007). Accounting choices under IFRS 1: analysis and determinants. Third annual workshop of the European Financial Reporting Research Group, ESSEC,Paris.

20. Boukari , M., Richard, J., (2007), "Les incidences comptables du passage des groupes français cotés aux IFRS", Comptabilité contrôle audit, Vol. Thématique, nDécembre, pp.155-170.

21. Fields, T., Lys, T., Vincent, L., (2001), "Empirical research on accounting choice", Journal of accounting and economics, Vol.31, n $1-3$, pp.255-307.

22. Watts, R., Zimmerman, J., (1990), "Positive accounting theory: a ten year perspective". The accounting review, Vol.65, ${ }^{\circ} 1$, pp.131-156.

23. Hand, J., Skantz, T., (1998), "The economic determinants of accounting choices: the unique case of equity carve-outs under SAB 51", Journal of accounting and economics, Vol.24, n², pp.175-203. 